\title{
Ю.C. Cnipir
}

Херсонська обласна клінічна лікарня

\section{Досвід впровадження операцій зі штучним кровообігом на базі відділення судинної хірургї̈ обласної лікарні}

Мета роботи - проаналізувати досвід впровадження в діяльність відділення судинної хірургії обласної лікарні операцій зі штучним кровообігом.

Матеріали і методи. Проаналізовано ситуацію з наданням кардіохірургічної допомоги в Херсонській обласній клінічній лікарні за 2010-2016 рр. Протягом 2010 р. відділення судинної хірургії, реанімаційне відділення та лабораторію Херсонської обласної клінічної лікарні доукомплектовано медичним обладнанням, необхідним для виконання операцій зі штучним кровообігом. Судинні хірурги лікарні пройшли первинну спеціалізацію за спеціальністю «Хірургія серця та магістральних судин». Організовано 24 виїзних майстер-класи на базі лікарні та 28 стажувань на робочому місті в провідних кардіохірургічних клініках України. Виконано 120 коронарних анастомозів на свинячому серці. Загалом протягом 2010-2016 рр. здійснено 215 операцій зі штучним кровообігом.

Результати. Трансформація відділення судинної хірургії у відділення серцево-судинної хірургії Херсонської обласної клінічної лікарні була оптимальним варіантом розвитку кардіохірургії з урахуванням реалій регіональної медицини. Організація численних виїзних майстер-класів та стажувань на робочому місці, тренування з проведення аортокоронарного шунтування на свинячому серці дозволили поступово опанувати методики операцій зі штучним кровообігом без тривалого відриву лікарів закладу від основного місця роботи та не знизити при цьому якість виконання ними основної роботи. Частота післяопераційних ускладнень становила 6,3 \%, летальність - 2,3\%.

Висновок. Розроблені шляхи впровадження операцій зі штучним кровообігом дозволили отримати позитивний безпосередній результат у 97,7 \% випадків, не знизивши якість роботи чинної системи надання хірургічної допомоги хворим із судинною патологією.

Ключові слова: штучний кровообіг, впровадження, судинна хірургія.

Посилання: Спірін Ю.С. Досвід впровадження операцій зі штучним кровообігом на базі відділення судинної хірургії обласної лікарні // Кардіохірургія та інтервенційна кардіологія.- 2018.- № 2.- С. 58-62.

To cite this article: Spirin YuS. Experience of the introduction of surgery with artificial circulation in the regional department of vascular surgery. Cardiac Surgery and Interventional Cardiology. 2018; 2(21):58-62 (in Ukr.).

$\Pi$ ротягом останніх десятиліть кардіохірургічні втручання набули значного поширення. Спектр їх досить різноманітний - від аортокоронарного шунтування до видалення рідкісних форм пухлин серця та оперативного лікування тромбоемболії легеневої артерії [1,
2, 4]. Однак впровадження операцій зі штучним кровообігом на регіональному рівні $€$ вкрай складним завданням, особливо для невеликих регіонів України. Зокрема в Херсонській області до недавнього часу проблема виконання подібних втручань взагалі не 
була вирішена. Це пов'язано з низкою організаційних проблем.

Перша проблема - необхідність створювати повністю нову матеріально-технічну базу. Це, перш за все, придбання кардіохірургічного обладнання та відповідно створення нового кардіохірургічного відділення, що потребує великих інвестицій з боку держави. Друга проблема - це укомплектування нової служби висококваліфікованими кадрами. Для виконання операцій зі штучним кровообігом необхідна мультидисциплінарна команда. Наступна проблема - навчання команди спеціалістів особливостям операцій зі штучним кровообігом. Підготовка такої команди з «нуля» потребує досить великих затрат часу. Особливо це стосується бригади кардіохірургів. В Україні процес навчання на курсах первинної спеціалізації зі спеціальності «Хірургія серця та магістральних судин» на момент 2010 р. становив 4 місяці, що вочевидь вкрай недостатньо для початку самостійної роботи. Підготовка спеціалістів одразу після закінчення інтернатури, ймовірно, є оптимальним шляхом, але в реаліях сучасної медицини України потребує багато часу, однак може розглядатися як варіант вирішення проблеми.

Отже, вирішення всіх зазначених вище питань - це актуальне завдання при створенні принципово нового напрямку (кардіохірургія) роботи служби надання хірургічної допомоги пацієнтам із серцево-судинними захворюваннями в невеликому регіоні.

Мета роботи - проаналізувати досвід впровадження в діяльність відділення судинної хірургії обласної лікарні операцій зі штучним кровообігом.

\section{Матеріали і методи}

Відділення судинної хірургії Херсонської обласної клінічної лікарні було доукомплектоване необхідним медичним устаткуванням: апарат штучного кровообігу, набір кардіохірургічного інструментарію, дефібрилятори, сучасні світильники, хірургічні оптичні системи, ЕКГ-монітори тощо. Кількість ліжок відділення (15) лишилася незмінною. Також реанімаційне і лабораторне відділення лікарні були доукомплектовані спеціальним обладнанням (кардіомоніторами, газовим аналізатором тощо).

Навчання кардіохірургів проводили за спеціально розробленою програмою, яка була адаптована до реалій сучасної медицини Херсонської області. Головним завданням програми навчання було придбання навиків проведення операцій зі штучним кровообігом, при цьому суттєво не зменшити кількість операцій, які виконувалися у відділенні за напрямком судинна хірургія та інтервенційна радіологія. Отже, навчання лікарів мало проводитися без довгого відриву від основного місця роботи.

Початковий етап навчання - первинна спеціалізація на базі Національної медичної академії післядипломної освіти імені П.Л. Шупика за спеціальністю «Хірургія серця та магістральних судин», навчання за програмою - 4 місяці. Далі протягом 2010-2013 рр. лікарі відділення пройшли численні курси тематичного вдосконалення 3 різних тематик, що стосуються штучного кровообігу. Важливою частиною навчання було проведення майстер-класів на базі Херсонської обласної клінічної лікарні із залученням провідних кардіохірургів України. На початкових етапах головна тематика майстер-класів була присвячена хірургічному лікуванню набутих вад мітрального та аортального клапанів. За період 2010-2012 рр. виконано 30 операцій протезування клапанів механічними протезами. У 5 випадках здійснено пластику дефекту міжпередсердної перегородки, зокрема в одному випадку - операцію при частковому аномальному дренажу. В одному випадку виконано видалення міксоми лівого передсердя. Загалом за цей період було проведено 18 майстер-класів на базі лікарні. Починаючи з 2013 р., додалися операції аортокоронарного шунтування (10) та втручання з приводу інфекційного ендокардиту (3). Загалом за 2013 р. виконано 25 операцій та організовано 10 майстер-класів. Надалі протягом 20142016 рр. тематика майстер-класів змінилася: три 3 них були присвячені виконанню аортокоронарного шунтування на серці, що працює, та три виконанню комбінованих втручань (протезування клапанів та коронарне шунтування). Загалом проведено 6 майстер-класів. Також протягом досліджуваного періоду фахівці відділення постійно проходили стажування на робочому місці в провідних кардіохірургічних установах України: Інститут серця МОЗ України, Національний інститут серцево-судинної хірургії імені М.М. Амосова НАМН України, відділення кардіохірургії Одеської обласної клінічної лікарні. Тематика стажувань також була регламентована та збігалася з тематикою проведення майстеркласів. Загалом проведено 28 стажувань. Украй важливим етапом навчання було тренування формування анастомозів між коронарною артерією та веною на свинячому серці. Тренування проводили таким чином. На макропрепараті свинячого серця виділяли коронарні артерії, розкривали їх просвіт. Слід зазначити, що розмір свинячого серця та діаметр коронарних артерій при-

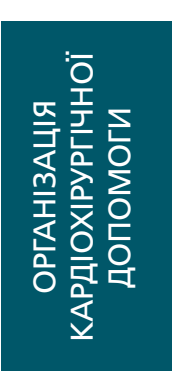


Таблиця

Динаміка та спектр оперативних втручань зі штучним кровообігом

\begin{tabular}{lccccc}
\hline Роки & $\mathbf{2 0 1 0 - 2 0 1 2}$ & $\mathbf{2 0 1 3}$ & $\mathbf{2 0 1 4}$ & $\mathbf{2 0 1 5}$ & $\mathbf{2 0 1 6}$ \\
\hline Аортокоронарне шунтування & & 10 & 20 & 22 & 48 \\
\hline Протезування клапанів & 30 & 15 & 11 & 15 & 23 \\
\hline Комбіновані операції & & & 4 & 3 & 3 \\
\hline Операції при природжених вадах серця & 5 & & 3 & 2 \\
\hline Видалення міксоми & 1 & 25 & 35 & 43 & 77 \\
\hline Разом & 36 & & & & 1 \\
\hline
\end{tabular}

близно відповідає розмірам серця людини. Далі брали заздалегідь видалену з бичачого серця коронарну артерію, розмір якої також приблизно збігався із середнім діаметром великої підшкірної вени людини. Далі, використовуючи мікрохірургічний інструментарій, проводили формування анастомозу між свинячою та бичачою коронарними артеріями. Загалом за період дослідження виконано 120 анастомозів. Середній час формування анастомозу на початку періоду тренування становив $(20,0 \pm 2,3)$ хв, у кінці $(10,0 \pm 1,9)$ хв на заключних фазах. Динаміку кількості та спектр впроваджених операцій зі штучним кровообігом у регіоні наведено в таблиuі. Період дослідження становив 2010-2016 рр. Під час дослідження оцінювали такі показники: динаміка та спектр виконаних оперативних втручань, післяопераційна летальність, частота та характер післяопераційних ускладнень.

\section{Результати та обговорення}

Аналізуючи досвід впровадження операцій зі штучним кровообігом на базі відділення судинної хірургії, можна виділити такі особливості.

Вирішення питання створення матеріальнотехнічної бази за напрямком кардіохірургія Херсонської обласної клінічної лікарні розпочалося $з 2010$ р. Обрано чіткий напрямок розв’язання проблеми - реконструкцію відділення судинної хірургії з центром інтервенційної радіології у відділення серцево-судинної хірургії 3 центром інтервенційної радіології. При такому підході не було необхідності створення нових кардіохірургічного, реанімаційного та лабораторного відділень, що є вкрай важливим в умовах недостатнього та нерегулярного фінансування медичної галузі регіону. Реконструкція баз лікарні дозволила суттєво знизити собівартість проекту та значно зменшити час його реалізації. Кадрове питання також було вирішено найпростішим та найшвидшим способом: медичні працівники, які працюють у закладі (судинні хірур- ги, анестезіологи, реаніматологи, кардіологи, лікарі-лаборанти та судинні медичні операційні сестри), були залучені до виконання операцій зі штучним кровообігом. Додатково була введена одна штатна одиниця - лікар-перфузіолог. Вважаємо, що введення нових ставок для створення служби (як-то кардіохірург, кардіоанестезіолог, реаніматолог та інші) не є раціональним та економічно ефективним в умовах постійного скорочення штату лікарні. Термін навчання за спеціальністю «Хірургія серця та магістральних судин» 4 місяці є вкрай малим та недостатнім для початку самостійного виконання операцій на регіональному рівні. Тому важливе значення в навчанні мультидисциплінарної команди фахівців відіграли чітко сплановані за тематикою виїзні майстер-класи та стажування на робочому місці в провідних клініках України.

Впровадження операцій зі штучним кровообігом, на наш погляд, слід починати з простіших планових операцій - протезування мітрального та аортального клапана при їх ревматичному та атеросклеротичному генезі та дефекті міжпередсердної перегородки. Однак кількість таких пацієнтів відносно невелика. Тому для регіонального рівня, задля підвищення загальної кількості оперативних втручань, важливе значення в лікуванні клапанної патології має впровадження методик хірургічного лікування інфекційного ендокардиту. Останній, з різних причин, у клінічній практиці трапляється все частіше [3]. Однак для цього потрібне додаткове проходження курсів тематичного вдосконалення, організація майстер-класів та тематичних стажувань. Виконання пластичних та транскатетерних операцій на мітральному клапані, безумовно, є важливим етапом розвитку кардіохірургії [5, 6]. Однак на регіональному рівні для цього потрібні досить великі фінансові інвестиції для придбання спеціалізованого обладнання, що не завжди можливо. Тому це безумовно перспективний напрямок, але в нашому дослідженні через брак фінансування він не розвивався. 
У формуванні стабільного потоку пацієнтів, скерованих на оперативні втручання, значну роль відіграє ішемічна хвороба серця. Для їі лікування необхідно володіти технікою виконання коронарного шунтування [7]. Формування коронарного анастомозу - на перший погляд, нескладна хірургічна маніпуляція, однак на практиці вона потребує великої теоретичної та практичної бази, ювелірної техніки володіння мікрохірургічним інструментарієм. Тому, окрім зазначених вище форм навчання, протягом періоду дослідження виконано більше 100 міжсудинних анастомозів на свинячому серці. В сукупності це дало змогу оволодіти та впровадити в роботу відділення операції аортокоронарного шунтування, які і стали формувати основний потік операцій.

Аналізуючи впровадження нової технології, слід відзначити такі результати. Загалом за період дослідження виконано 215 операцій. Кількість операцій поступово але стабільно зростала (від 18 за рік на початку роботи до 77 протягом 2016 р.), а спектр операцій постійно розширювався (від протезування мітрального клапана до виконання комбінованих операцій). Слід зауважити, що протягом тільки 6 місяців 2017 р. уже виконано 58 оперативних втручань зі штучним кровообігом. При цьому, як і було заплановано, за весь період впровадження в лікарні операцій зі штучним кровообігом кількість інших втручань, які виконувалися у відділенні судинної хірургії, не зменшилася (отже, впровадження принципово нової технології не знизило якість роботи за

Конфлікту інтересів немає.

\section{Література}

1. Коноплева Л.Ф., Кушнир С.Л. Опухоли сердца. Возможности клинической диагностики // Серце і судини.- 2013.№ 2.- C. 23-26.

2. Кундін В.І., Сатир М.В., Новерко В.І. та інші. Можливість перфузійної сцинтиграфії легень у діагностики тромбоемболії легеневої артерії та хронічної тромбоемболічної легеневої гіпертензії // Кардіохірургія та інтервенційна кардіологія.- 2017.- № 2.- С. 33-39.

3. Руденко Ю.В., Безродный А.Б. Рекомендации по профилактике, диагностике и лечению инфекционного эндокардита Европейского общества кардиологов // Серце судини.- 2011.- № 1.- С. 20-34.

4. Руденко Ю.В., Ковалева И.С., Стременюк О.Т. Рекомендации Европейского общества кардиологов 2013 года по ведению пациентов с хроническими формами основними напрямками). Кількість ускладнень становила 6,3\% (13 пацієнтів). А спектр іх був традиційний для подібних операцій: гемоторакс (1), інфекційний ендокардит протезованого клапана (1), інфаркт міокарда та гостра серцевосудинна недостатність (3), післяопераційна кровотеча (1), гостре порушення мозкового кровообігу (2), гострий панкреонекроз та тромбоз артерій кишечника (1), гостра ниркова недостатність (2), гостра поліорганна недостатність септичного генезу (2). Загальна летальність становила 2,3 \% (5 пацієнтів). Причини летальності - інфекційний ендокардит протезу клапана, панкреонекроз, гостра поліорганна недостатність. В інших випадках хворі виписані з одужанням, частота позитивних безпосередніх результатів становила $97,7 \%$.

\section{Висновки}

Реконструкція відділення судинної хірургії може бути одним з економічно обгрунтованих шляхів розвитку кардіохірургії на регіональному рівні. Організація виїзних майстер-класів та стажувань на робочому місці - важливий компонент навчання операціям зі штучним кровообігом в умовах реалій сучасної медицини регіону. Розроблені шляхи впровадження операцій дозволили отримати позитивний безпосередній результат у 97,7 \% випадків, не знизивши якість роботи чинної системи надання хірургічної допомоги хворим із судинною патологією. ишемической болезни сердца // Серце і судини.- 2014.№ 1.- C. 8-18.

5. Acker M.A., Parides M.K., Perrault L.P. et al. Mitral-valve repair versus replacement for severe ischemic mitral regurgitation // New Engl. J. Med.- 2014.- Vol. 370.P. 23-32.

6. Baldus S., Schillinger W., Franzen O. et al. MitraClip therapy in daily clinical practice: initial results from the German transcatheter mitral valve interventions (TRAMI) registry // Eur. J. Heart Fail.- 2012.- Vol. 14.- P. 1050-1055.

7. Windecker S., Kolh P., Alfonso F. et al. 2014 ESC/EACTS Guidelines on Myocardial Revascularization of the European Society of Cardiology (ESC) and The European Association for Cardio-Thoracic Surgery (EACTS) // Eur. Heart J.- 2014.Vol. 35.- P. 2541-2619. 


\title{
Ю.С. Спирин \\ Херсонская областная клиническая больница \\ Опыт внедрения операций с искусственным кровообращением на базе отделения сосудистой хирургии областной больницы
}

\begin{abstract}
Цель работы - проанализировать опыт внедрения в практику отделения сосудистой хирургии областной больницы операций с искусственным кровообращением.

Материалы и методы. Проанализирована ситуация с оказанием кардиохирургической помощи в Херсонской областной клинической больнице в 2010-2016 гг. На протяжении 2010 г. отделение сосудистой хирургии, реанимация и лаборатория Херсонской областной клинической больницы были доукомплектованы медицинским оборудованием, необходимым для выполнения операций с искусственным кровообращением. Сосудистые хирурги больницы прошли первичную специализацию по специальности «Хирургия сердца и магистральных сосудов». Организовано 24 мастер-класса на базе больницы и 28 стажировок на рабочем месте в ведущих кардиохирургических клиниках Украины. Выполнено 120 коронарных анастомозов на свином сердце. На протяжении 2010-2016 гг. проведено 215 операций с искусственным кровообращением.

Результаты. Трансформация отделения сосудистой хирургии в отделение сердечно-сосудистой хирургии была оптимальным вариантом развития кардиохирургии с учетом реалий региональной медицины. Организация мастер-классов и стажировок на рабочем месте, отработка техники аортокоронарного шунтирования на свином сердце позволили освоить методики операций с искусственным кровообращением без долгосрочного отрыва от основного места работы врачей больницы и не снизить качество выполняемой ими основной работы. Частота послеоперационных осложнений составила 6,3 \%, летальность - 2,3 \%.

Выводы. Разработанные пути внедрения операций с искусственным кровообращением позволили получить позитивный непосредственный результат в 97,7 \% случаев, не снизив качество работы существующей системы оказания хирургической помощи пациентам с сосудистой патологией.
\end{abstract}

Ключевые слова: искусственное кровообращение, внедрение, сосудистая хирургия.

\section{Yu.S. Spirin \\ Kherson Regional Clinical Hospital, Kherson, Ukraine \\ Experience of the introduction of surgery with artificial circulation in the regional department of vascular surgery}

The aim - introduction of surgery with artificial circulation in the regional department of vascular surgery.

Materials and methods. In 2010 department of vascular surgery, intensive care unit and laboratory of the Kherson regional hospital were completed with special medical equipment needed to perform procedures with artificial circulation. Vascular surgeons received certificate «Surgery of heart and main vessels». 24 master classes and 28 training courses in the leading Ukrainian cardiac surgery clinics were organized. 120 coronary anastomoses were performed on pig hearts. During 2010-2016 years 215 procedures with artificial circulation were performed.

Results. Transformation of the vascular surgery department to the cardiovascular surgery was an optimal way of introduction of cardiac surgery considering features of the regional medicine in Ukraine. Organization of the master classes, training courses and coronary bypass surgery procedures on the pig hearts made possible to develop regional cardiac surgery without long-term interruption of the usual process and without influence upon quality of the work. Postoperative complication rate was $6.3 \%$ and mortality was $2.3 \%$.

Conclusions. Introduction of the surgery with artificial circulation led to immediate positive results in $97.7 \%$ of cases without negative influence upon existing system of the management of vascular pathology.

Key words: artificial circulation, introduction, vascular surgery. 